Global health

\section{From charity to rights: proposal for five action areas of global health}

Ilona Kickbusch

\section{Towards a global social contract on health}

fo

believe that we are at a turning point

for public health-and that our

choices are stark: either we reorient and strengthen public health within both modern and developing societies and institute a resilient system of global governance for health or we will face dire consequences in terms of human, social, and economic development. At present, it is the poorest countries that are paying the price for this negligence-but we have mounting signals that a new health divide is in the making as a large global underclass spreads out around the globe and defies the old definitions of vulnerable groups.

Forceful action at nation state level will not be enough-we need nothing less than a new global social contract on health. I was delighted to see the use of that phrase also by Richard Smith, editor of the British Medical Journal in a recent excellent editorial. ${ }^{1}$ The drive for such a contract can only be established politically-developed through an ethical and political debate throughout society initiated by outspoken public health professionals, responsible politicians, and a concerned civil society at national and global levels of governance. And maybe this is the time for the respective journals to make this a joint wake up call to our professional community.

We have reached a point where we need to make a choice of what kind of model of global public health we want to promote. It was one of the characteristics of modernity to take health out of the confines of religion and charity and make it a key element of the action of the state and the rights of citizenship. This process, initially within the context of the constitution of the nation state, today needs to go global as a key dimension of global justice. The International Labour Organization with its recent report on globalisation has presented some first steps in this direction. With such a perspective we can see that the present global drive for access to AIDS medicines for developing nations is not just about health, it is the spearhead of a global citizenship movement that has recognised that global health needs to move out of the charity mode of bilateral aid and philanthropy into the realm of rights, citizenship, and a global contract. With this in mind I would like to propose five key action areas for a global public health:

\section{DEFINE HEALTH AS A GLOBAL PUBLIC GOOD}

This implies ensuring the value of health, understanding it as a key dimension of global citizenship, and keeping it high on the global political agenda. It implies defining common agendas, increasing the importance of global health treaties, and increasing pooling of sovereignty by nation states in the area of health. It also implies a new interface between foreign and domestic policies. Finally it means new forms of sharing of research and proprietary information to resolve common health challenges.

\section{ACCEPT HEALTH AS A KEY COMPONENT OF GLOBAL SECURITY}

This implies an extensive global health surveillance role and expanded international health regulations with interventionist power for the World Health Organisation and sanctions (through other bodies such as the World Trade Organisation of the International Court of Justice) for countries that do not comply-the reliable financing of a global surveillance infrastructure and a rapid health response force would be ensured through a new kind of global financing mechanism or a global public goods tax, for example on airline tickets and tourism.

\section{STRENGTHEN GLOBAL HEALTH GOVERNANCE FOR INTERDEPENDENCE}

This means strengthening the WHO and giving it a new and stronger mandate. It must have the constitutional capability to ensure agenda coherence in global health, it must be able to strengthen its convening capabilities, and it should be able to ensure transparency and accountability in global health governance through a new kind of reporting system that is requested of all international health actors. Indeed recognition of its coordination and leadership role should significantly reduce the transaction costs for countries and for donors and should include a brokering role in relation to the health impacts of policies of other agencies. It should also be the coordinator of health in crises by acting as the intermediate health authority. Furthermore, it should gain more coordinating power for the actions necessary to reach the Millennium Development Goals (MDGs) on health.

\section{ACCEPT HEALTH AS A KEY FACTOR OF SOUND BUSINESS PRACTICE AND SOCIAL RESPONSIBILITY}

This falls squarely into the realm of the Millennium Development Compact and the Global Compact as well as Goal 8 of the MDGs. There is an enormous scope for business involvement in development, not only in form of the public private partnerships around diseases but also-as the work on nutrition has shown-for producing and marketing healthy and safe products to the poorsuch new business models could be part of the work of the World Economic Forum. The International Business Leaders Forum has produced an excellent guide how business can contribute to the achievement of the MDGs.

It also means increasing the capacity of the WHO to negotiate a new system of access to drugs based on a global public goods model for example in the area of pricing (for example, joint negotiations of 10 Latin American Countries and PAHO with global players on Anti Retro Viral drugs led to a $92 \%$ price reduction). Clearly legally binding Global Health Conventions such as the Framework Convention on Tobacco Control must be further developed and strengthened. But even more important is to work on new financing models, such as the International Finance Facility proposed by Gordon Brown the British Chancellor of the Exchequer or a model package of a global Bismarckian type of health insurance together with the insurance industry and the ILO and the World Bank. There is an urgent need to establish a system to ensure how contributions of the rich world ensure access to prevention, care, and treatment in developing countries. Clearly health and social protection cannot be separated.

\section{ACCEPT THE ETHICAL PRINCIPLE OF HEALTH AS GLOBAL CITIZENSHIP}

This means working to develop a common notion of social justice and a system of international law where human rights constitute a legal claim.

In the next wave of modernity that now sweeps the globe social protection 
becomes a global challenge. As many recent analyses ${ }^{2}$ have shown the global institutions have focused on the global public goods necessary to the expansion of trade and commerce but have severely neglected the expansion of social public goods. This is exactly where we are challenged as a public health community today. What we need are public health models that take radically different approaches and question the very premise of what at the global level is a public and what is a private good.

$J$ Epidemiol Community Health

2004;58:630-631.

doi: 10.1136/jech.2004.021121

Correspondence to: Professor I Kickbusch, Yale University/PAHO, Pan American Health Organization Office of the DPM, 525 23rd Street NW, Washington DC 20037, USA; kickbusi@paho.org

\section{The dangers of "spin": information, science, security, and welfare}

\section{Nancy Milio}

\section{Restrictions on full and accurate information}

$\mathrm{T}$ he Bush administration may go down in American history as one of the most creative, or devious, (depending on your point of view) in its use or misuse of information. Other nations can take a lesson from its lethal language. The US public has been focusing on a basic ingredient of democracy: truth in government, the practice of transparency and full disclosure. In public hearings before a special national investigating commission on intelligence and the September 11, 2001 terrorist attacks on the US, the government's practice is found wanting as the public witnessed and listened to the word games of administration officials. The entire history of open information use in the Bush regime is discouraging. The list is long. A few examples:

Going beyond the Patriot Act, (which was passed hurriedly by Congress without debate after September 11 and greatly increased national security agencies' ability to encroach on civil liberties), the attorney general recently got what he has long sought, buried in new legislation: an extension of the FBI's authority to get individuals' financial records from private organisations ranging from credit card companies and car dealers to jewellers and the Post Office, without normal judicial review or showing "probable cause" of a crime. It also imposes a "gag" order under threat of criminal penalty for anyone who discloses that the FBI has obtained such records. In addition, the FBI is no longer required to report to Congress on how often they use this power.

The Department of Defense now restricts unclassified (non-secret) information on its web site, deleting what it deems is "of questionable value to public" and anything not "specifically approved for public release".

The US Iraq press office in Baghdad is basically a Republican party operation, run by political appointees who have worked on Bush election campaigns, for the Bush family, or in the administration. Its stated task is to communicate to Congress and Americans the positive side of the invasion, occupation, and reconstruction. It targeted "good news" to US media in selected states prior to the recent Democratic presidential nomination primary elections. By comparison, the British press office is staffed by long time civil servants, not political appointees, who have specialist regional knowledge and language skills; the US has five staff who know enough Arabic to be interviewed on Al Jazeera TV.

For two years Vice President Cheney has fought providing information to Congress and the public on the input of the energy industries in the formulation of the administration's fossil fuel favoured energy policy. The final decision is awaiting resolution by the Supreme Court, whose Justice Antonin Scalia recently went on a hunting trip with the vice president.

The administration understated the cost of the new Medicare prescription drug law for the elderly population and disabled people by $\$ 140$ billion until after it was passed by Congress, even though a government actuary had provided it with the true cost, which it refused to accept before the legislation was written; the actuary resigned in protest.

Congress' General Accounting Office, which investigates policy implementation, cited 21 areas of Executive authority
These ideas were developed in more detail on occasion of the Leavell lectureship of the World Federation of Public Health Associations, Brighton, April 2004

\section{REFERENCES}

1 Smith R. Towards a global social contract. BMJ 2004:328: 3 Apr:editor's choice.

2 Inge K, Conceicao P, Le Goulven K, et al Providing global public goods: managing globalization. New York: UNDP, 2003.

that abused science information, including "political interference" and suppressing scientific reports; allowing misleading science statements by the president; providing inaccurate information to Congress; altering web sites and gagging scientists. The topics most affected were those on the administration's political agenda, such as abstinence-only sex education; purported negative effects of abortions; drinking water and food safety, global warming, and workplace safety.

The administration's approach to information is to focus on threat risks but not on the benefits of information to Americans' security. This is erroneous, according to a new report by the highly regarded RAND Corporation think tank. It says web censorship is pointless because potential terrorists can get more detailed material from other open sources. Meanwhile, the benefits are lost by restricting government information, including better law enforcement, the spread of scientific knowledge, response to environmental risks and collaboration among citizens to prevent them.

All of these restrictions on full and accurate information damage civil liberties, respect for government, and ultimately the safety and security, the welfare and health of all who reside in the US, and indeed those in other countries-whether from false rationales for violence or denial of the science behind environmental damage, or of the most efficacious ways to deal with such health issues as HIV/AIDS and birth control.

A prime safeguard against government half truths and misleading information since the early US Republic is an alert, inquiring, and assertive media. But since 1989, the three TV networks' reporting of foreign news decreased from over 20 hours to less than five hours per week by 2003, as was true of most local newspapers, even though 6 in 10 readers say they are "highly interested" in foreign news. As a result, Americans are using new sources, with large increases in the audiences of the London Economist, the New York Times, Reuters wire service, and the BBC.

More worrisome is a current report of surveys running from 9 June 2002, 
before the Iraq invasion to September 2003, which shows that more than 6 in 10 Americans had misperceptions of facts about the war, believing, for example, that weapons of mass destruction were found; that Saddam had ties with Al Quaeda; and that world opinion favoured the US invasion. These erroneous beliefs were related to people's primary source of news. The most accurately informed used NPR (National
Public Radio) and read the newspapers; the least well informed used Fox TV, owned by Rupert Murdoch, who also owns Sky TV.

Without an informed citizenry, the kinds of governments and societies we want, the kinds the world respects, can shrivel, reaping disaster on the lives and living conditions ultimately of us all. Those especially in the helping professions who understand the need for truth

Data, "race", and politics

\section{Data, "race," and politics: a commentary on the epidemiological significance of California's Proposition 54}

\section{Nancy Krieger}

\section{The importance of the politics of data for epidemiological analyses}

D ata for social justice and public health are akin to the proverbial two edged sword. To the extent we base any of our claims about social injustice in evidence, we must use data-whether of the quantitative or qualitative sort. But data do not simply exist. By contrast with the literal definition of "data" as "that which is given," data instead are duly conceived and collected, via the ideas and labour of those who would obtain the requisite evidence. ${ }^{1}$ In the case of epidemiology, moreover, we must often use population data appearing in categories that are far from ideal-precisely because the assumptions of those with the power to shape and accrue the data often differ from those who seek to use these data to illuminate and oppose social inequalities in health.

Instructively highlighting these tensions are issues that recently arose in relation to the California ballot initiative Proposition 54..$^{2-4}$ Officially designated as the "Classification by Race, Ethnicity, Color, or National Origin Initiative" but called the "Racial Privacy Initiative" by its supporters (who previously sponsored the successful anti-affirmative action Proposition 209)-Proposition 54 sought to ban collection or use of racial/ethnic data by government agencies. $^{2-4}$ Under the slogan "Think outside the box," the initiative's proponents claimed Proposition 54 would "end government's preferential treatment based on race, and junk a 17th century racial classification system that has no place in 21 st century America." ${ }^{3}$

Despite its seemingly "progressive" approach to discounting outdated modes of classifying "race," Proposition 54 nevertheless was soundly defeated (64\% opposed) by a coalition lead in large part by public health advocates and researchers, who exposed how the absence of these data would translate to public harm, especially in relation to public health. ${ }^{2}{ }^{4}$ Recognising that not collecting data is a time honoured method of removing a problem from public purview, as if to say: "no data, no problem," ${ }^{1}$ the opponents argued Proposition 54 would effectively whitewash reality-by precluding monitoring of racial/ethnic disparities in health let alone developing programmes or allocating resources to address them.

To understand the conceptual issues at stake, highly relevant for both health research and public health monitoring. Figure 1 diagrams the three contrasting approaches to data on race/ethnicity informing arguments for and against Proposition 54. Tellingly, both proponents and opponents of Proposition 54 condemned racism and unscientific beliefs about "race" as an "innate" characteristic. But, whereas proponents argued that racial/ethnic data should not be collected because "race" is not "real" (that is, not "biological"), opponents countered that this stance patently ignored the social realities of "race" - that is, as a socially constructed and openness in government and the relentless search for truth by the media must speak openly for this imperative to states and in the media.

$J$ Epidemiol Community Health 2004;58:631-632

doi: $10.1136 /$ jech. 2004.024307

Correspondence to: Professor N Milio, University of North Carolina, Carrington Hall no 7460, Chapel Hill, NC 27599-7460, USA; milio@email.unc.edu

\section{Key points}

- California's Proposition 54 which sought to ban state agencies from collecting or using racial/ethnic data, was defeated by a coalition largely led by public health researchers and advocates

- Both proponents and opponents denounced racism and rejected "race" as a "biological" category

- Whereas proponents claimed "race" was therefore not "real" opponents argued the social realities of "race" and ongoing racism required collecting the data to monitor social inequalities in health and other outcomes

- These debates reveal complex concerns about data relevant to epidemiological analyses of population health

category reflecting societal and individual histories of racial discrimination and dispossession.

The contradiction is therefore sharpand unavoidable-and affects all research using categories that bear the mark of social inequality. Data on social disparities in health have long been disparately interpreted as evidence of

\section{Policy implications}

- California's Proposition 54 would have seriously harmed efforts to monitor and address racial/ ethnic disparities in health.

- Epidemiological analyses should explicitly expose issues of social injustice whenever using social categories linked to social inequality. 


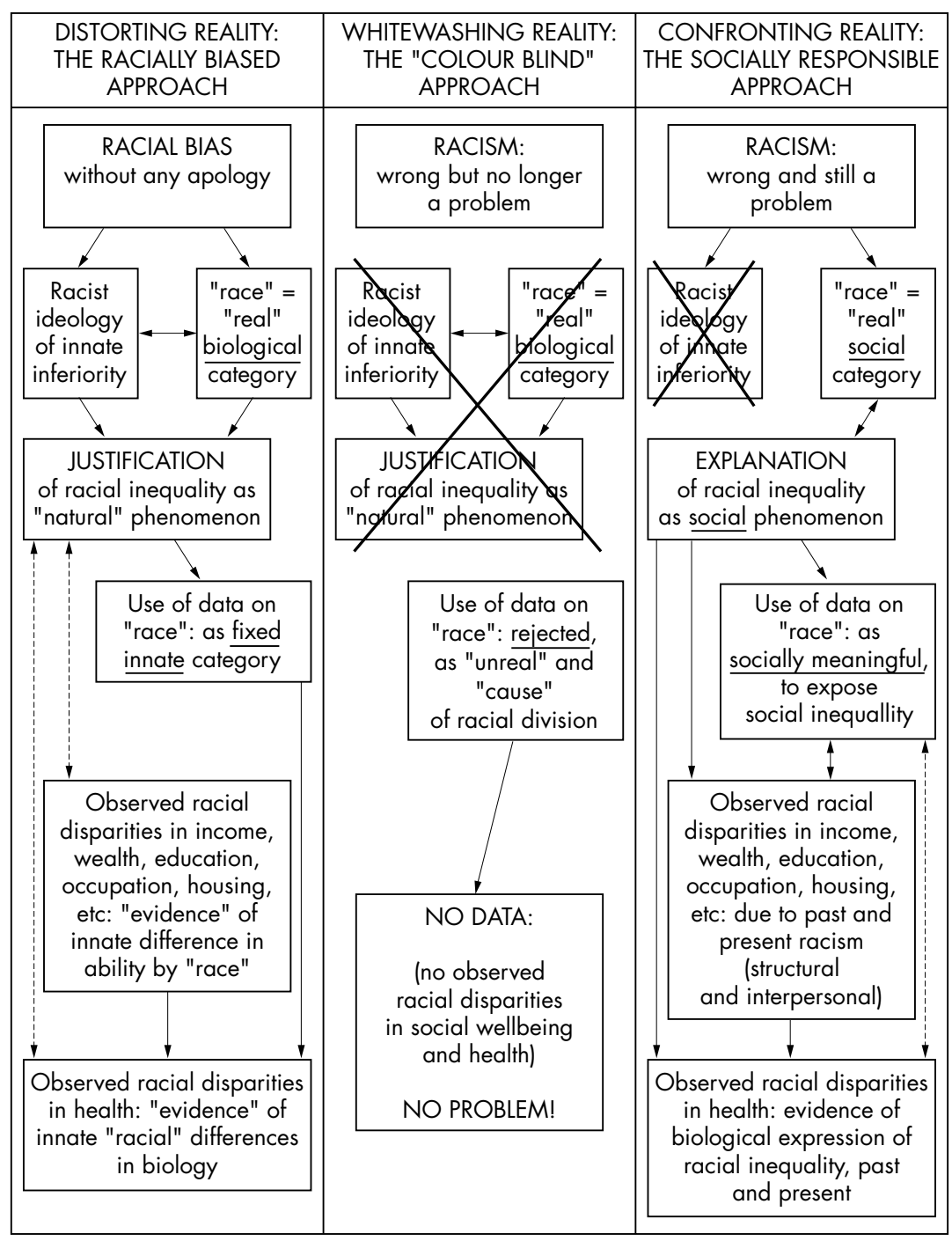

Figure 1 Divergent conceptual approaches to racial/ethnic data at play in the debate over California's Proposition 54. (a) "innate" inferiority, (b) "cultural" inferiority, or (c) embodied consequences of social inequity. ${ }^{5}$ There is no "thinking outside of the box" devoid of context. In the case of racial/ethnic inequalities in health, when "colour" is no longer a signal for denial of human dignity and human rights, we will live in - and the data will show-a multihued society with equality for all. Only by bringing into the open the issues of power and injustice that lie behind the "that which is given" of public health data can we work honestly with the data to promote social justice and human rights, which together comprise the foundation of public health.

$J$ Epidemiol Community Health 2004;58:632-633.

doi: 10.1136/jech.2003.018549

Correspondence to: Professor N Krieger, Department of Society, Human Development and Health, Harvard Śchool of Public Health, 677 Huntington Avenue, Boston, MA 02115, USA; nkrieger@hsph.harvard.edu

\section{REFERENCES}

1 Krieger $\mathbf{N}$. The making of public health data: paradigms, politics, and policy. J Public Health Policy 1992; 13:412-27.

2 Coalition for an Informed California. Vote No on Prop 54. http://www.defeat54.org/ laccessed 25 Nov 2003)

3 Racial Privacy Initiative. Proposition 54. http:// www.racialprivacy.org/ (accessed $25 \mathrm{Nov}$ 2003).

4 Schevitz T. Prop. 54 defeated soundly-State initiative on racial privacy raised issues about health, education. San Francisco Chronicle 2003; Oct 8. http://sfgate.com/cgi-bin/ article.cgi? file $=$ /chronicle/archive $/ 2003$ / 10/08/MN215579.DTL (accessed 25 Nov 2003).

5 Krieger N. Embodying inequality: a review of concepts, measures, and methods for studying health consequences of discrimination. Int $J$ Health Serv 1999;29:295-352.

\section{THE JECH GALLERY}

\section{Life and death, day after day}

T he image, a corridor outside a medical ward in a main hospital of an African country, was taken around the time dedicated for family visits. A dead body, being carried to the morgue, some visitors and others are part of the day to day scenario in some settings. In countries ravaged by high mortality rates for various reasons, it could seem "normal" to walk between dead bodies and live ones. In fact, that is life for millions of people... to live at the edge of death.

J Jaime Miranda International Health and Medical Education Centre, University College London, The Archway Campus, Union Building, 2-10 Highgate Hill, London N19 5LW, UK; j.miranda@ucl.ac.uk

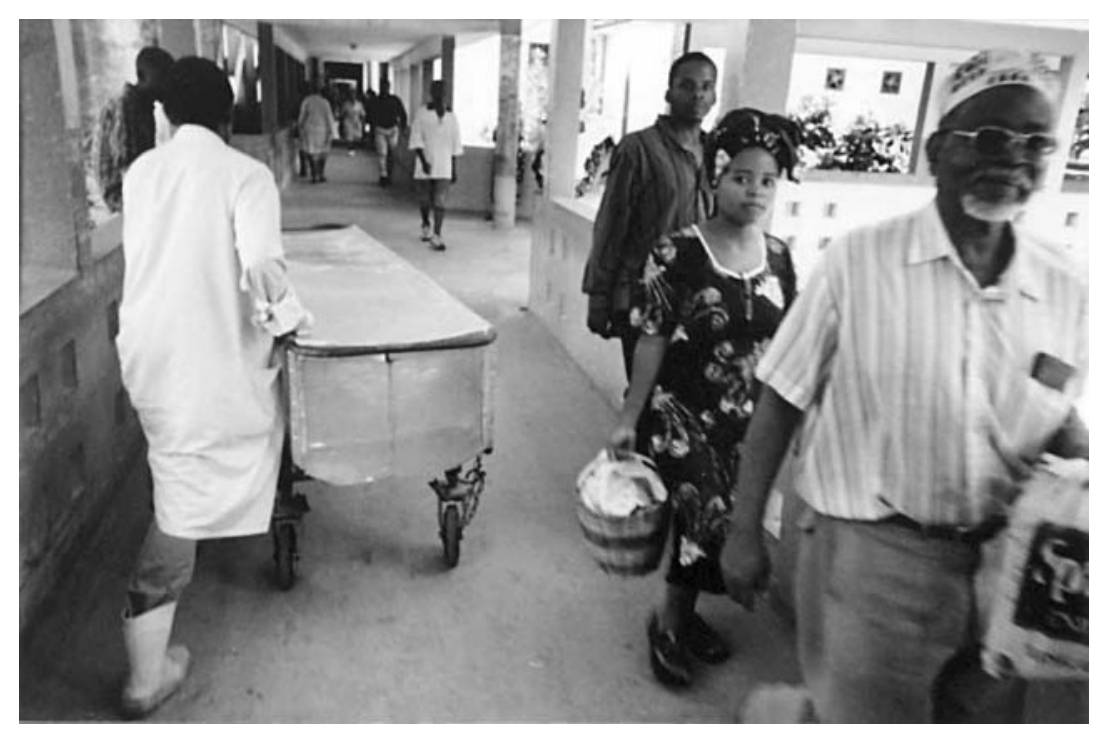

